\title{
Supervisors in ergonomic change of meat cutting work
}

\author{
Vogel, K. \\ Department of Ergonomics, KTH Royal Institute of Technology, STH, , Alfred Nobels Allé 10, SE-141 52 \\ Huddinge, Sweden kjerstin.vogel@kth.sth.se
}

\begin{abstract}
Being a supervisor is an important and lonely occupation. The aim of this study was to identify barriers and opportunities in working conditions for supervisors, being facilitators and implementers of change for meat cutters. Nine supervisors of meat cutters in one large company were interviewed. The semi-structured interviews covered their roles as supervisors, performance of the change process and their own working conditions. Notes were taken and structured in themes. Similarities, differences, plus and minus were identified. There was a nuanced view on the change processes and their effects. The change processes and the decisions were anchored in a democratic process with groups of employees and the union. All were clear on what demands the company had on them. They were secure in a functioning network of peers and their immediate superior. On their own education, most were as a whole satisfied, but in need of more training and talked of lifelong learning. They considered their work demanding and lonely, with a need both to be manager and leader. A shared leadership could mean doing a better job. There is a need for education and training as a manager and leader as well as the opportunity to discuss with peers.
\end{abstract}

Keywords: Manager, leader, work environment, meat cutter, improvement

\section{Introduction}

The supervisor is very important for the work environment of the staff. In the literature, management generally is defined as manager versus leader (Alvesson \& Sveningsson, 2003).

A leadership is always in a context in which all stakeholders affect each other. Employees are also affected by their superiors and may feel dependant on the supervisor. The supervisor's conduct may enhance or diminish well-being, security and performance of staff (Alvesson \& Sveningsson, 2003).

In Håkansson's dissertation (1995), she found no evidence for result of change dependant on who initiated the changes. Although, when the supervisors had the actual responsibility for the changes, results were better both for quality, delivery reliability and the individual's increased openness (ibid., p. 181). Håkansson concludes that a change project to be successful requires management's commitment and interest as well as staff time (ibid., p. 220).

Klein (1984), on the other hand, stresses the supervisors' role as supporters of change. When they are unable to see any interest for themselves or per- ceive a possible threat to their own work and thus opposes the implementation, a program has little chance of success. For success, management has to "walk the talk", i.e. to include supervisors in design and implementation of change and give them influence, in the same way other employees are included (ibid.).

Being a manager is not very glamorous but it is in everyday life most of the work takes place (Döös, Wilhelmson, \& Backström, 2010, p. 11). Everyday life lays the foundation for production and its output and thus also on the on the organization's functions. It can be contrasted by the other picture, with the manager as a front man: The one who takes all the grand and important decisions and has got the most power.

An authentic leader's role (Jackson \& Parry, 2008, p. 39), is to get the staff to perform their tasks as expected. The leader should be able to raise confidence and have integrity, provide security and rewards and to pay attention to their employees. It takes time to become a leader; manager is an appointment, but leadership requires wisdom and that has to be hardearned through personal experiences in social inter- 
action between individuals, groups and collectives. To be successful there is a need for reflections on one's leadership (Jackson \& Parry, 2008, p. 123). It is not possible only to study to become a leader; leadership requires practice and training (Seger \& Bergsten, 2007). The situation determines the leadership and production requires action, although the manager or leader rarely know the outcome (Holmberg \& Tyrstrup, 2010).

According to the literature (Badaracco \& Hansson, 2003), the objective of the managers or the leaders is to be a realist and pragmatic ( p. 19), and to be able to deal with difficult situations ( p. 94). Badaracco and Hansson (ibid.) give some guiding principles for a leader (p. 26):

- The future is uncertain and you will be surprised.

- Have plans, but be prepared to revise them.

- Have allies - but realize that when it comes down to reality, you stand alone.

Kaulio (2008) described project leadership from 48 respondents. His respondents described the most important problems they had to face in their projects. These problems were grouped in management issues respectively leadership issues and internal or external problems within the two previously mentioned groups. Here a clear picture emerged that most problems were related to personnel or individuals, and that project managers had more internal than external problems.

Sandahl, Falkenström, \& Knorring (2010) identified the contents of the different roles. They describe management issues as what should be done, and how to do it is a leadership aspect (p. 116). They clarify that the manager's moral responsibility is to create conditions for making business and money. If they fail with that, it's time to consider another business (p. 144).

Several authors (Alvesson \& Sveningsson, 2003; Badaracco \& Hansson, 2003; Kaulio, 2008; Yukl \& Lepsinger, 2005) have spent brain work at the roles as a manager/administrator and leader/visionary. A fairly new leadership role is the shared leadership (Döös, et al., 2010), but the majority of managers still manage businesses on their own. Yukl and Lepsinger (2005) has developed ideas on the importance of integrating the managing and the leadership roles in the same individual. In a flexible leadership there are three key elements that contribute to business performance. There are those dealing with efficiency, innovation and relationships. They complement and influence each other and their importance depends on the situation. Yukl and Lepsinger (ibid.) give many examples from the business world, but every company is unique and has to solve its own problems in its own ways. Yukl and Lepsinger further stresses that the leader has to understand his/ her company as well as the surrounding world. The leader has to have a systems thinking: complex problems have multiple causes. Also, it doesn't matter how good you are if not other persons in the organization are pulling towards the same goal, with the same commitment.

A shared leadership implies that two or more people share responsibility and authority for an activity (Döös, et al., 2010, p. 12). This however cannot be done, for legal reasons, on the highest level as a CEO or director-general. The advantages of shared leadership is, according to the authors, that two persons think better together, their own work situation is not so exposed, employee relations can improve and decisions becomes more well thought-out and thus more sustainable. Together with a colleague of equal merit, greater constructiveness and energy can be developed even in difficult or threatening situations (Döös, et al., 2010, p. 141). The positive examples that are available, suggest that shared leadership is also favorable, as such leadership provides a more transparent, accessible and quick to address problems leader. Negative experiences have demonstrated leaders who cannot share leadership by themselves, or his/her co-leader or a top management not being positive. In particular are those experiences negative where those who are to work together have not developed a common basis with common values to stand on.

\subsection{Industrial context}

Industrial production implies in brief that raw material comes in, is processed, refined and sent to sales. Within meat cutting this means that the quality of the raw material differs, it cannot be foretold, neither by quality or quantity. In everyday business, the leadership focuses on daily activities. Processes may have to be corrected, depending on unexpected events. Reactions from personnel, sales organization or other internal stakeholders can depend on the quality of the raw material, an occupational accident or another unforeseen event. In everyday business, therefore, leadership is often about rapid and clear decisions and taking strong action. Their production activities are not free of frictions and no two days are 
ever the same: "How many details at what quality do I get?", "Do I have the personnel needed today?", "Is there enough personnel with the right qualifications to be able to perform the specifications that we are to deliver today?" Questions are numerous; many people are insisting on attention and all demand their answers instantly (Holmberg \& Tyrstrup, 2010).

The Sweden based food company in focus processes and sells meat, cut up meat and various meat products under its own name. The company has got three plants. Each plant has its own steering committee. There is a joint steering committee for each production activity. This paper deals with meat cutting departments. In 2008 the Swedish Work Environment Authority put requirements on this company and four other large companies to improve working conditions for meat cutters. The requirements aimed at reducing work related occupational accidents and occupational diseases. Thus the requirements were primarily put on knife handling time, distribution of working time and breaks. Changes implemented involved structuring the working day into work periods of no longer than 90 minutes with pauses accordingly. Production flow rate was capped over the whole day and a steady workload for the individual was ensured. The largest change was in providing all meat cutters with one knife free work period a day, i.e. rotation to other tasks.

\section{Aim}

The aim of this study was to identify barriers and opportunities in working conditions for supervisors, being facilitators and implementers of change for meat cutters.

\section{Method}

This paper is part of an interactive research study, focusing on meat cutters. Other results are presented elsewhere (Karltun, 2010; Karltun, Aili, \& Vogel, 2011; Vogel, Karltun, \& Eklund, 2010). Nine supervisors of meat cutters in one large company were interviewed for about one hour by the author of this paper. The interviews were semi-structured along some topics: their roles as supervisors and how the change process was performed. These interviews were in parts similar to a questionnaire to meat cutters being in focus of changes (Vogel, et al., 2010).The supervisors' views on their own working conditions were also addressed. Notes were taken and written down and structured in themes. Similarities and differences, plus and minus were identified and categorized.

\section{Results}

There were eight men and one woman, all of them worked full time and two on night shift (Table 1)

Table 1

Description of participants. Mean and median figures and range

\begin{tabular}{llll} 
& Mean & Median & Range \\
\hline Age (years) & 44 & 41 & $38-55$ \\
Experience as a supervisor (years) & 4,17 & 2,16 & $0,6-10$ \\
Experience as a meat cutter (years) & 12 & 12 & $0-22$ \\
Experience in the business (years) & 23 & 21 & $16-37$ \\
Personnel responsibility for (persons) & 77 & 64 & $0-32$ \\
-of which were from temp agencies & 19 & 23 & \\
\hline
\end{tabular}

In the interviews the supervisors expressed a nuanced view on the change processes and their effects. They described the change processes and the decisions as anchored in a democratic process with groups of employees and the union. The change process was made in "the old fashioned negotiation way", as one of the respondents put it. That meant working committees consisting of the supervisor, safety representative, employees and others as members from the
Occupational Health and Safety Company used by the company. Other group constellations included head of safety representatives, plant manager and others as from the technical department. Their work was held on several levels; it anchored decisions with the trade union as well as having meetings to discuss and plan the practical sides of implementing the changes. All but one felt involved in the process. The other eight supervisors were pleased with the process. 
They exemplified by describing numerous discussions held among the employees. In their opinion, that was evidence on the changes being anchored with the employees.

There was no clear view on the results of the changes; the supervisors expressed different views on how the productivity, yield and quality were affected. They were clear on the growing demands on meat cutters to be flexible and perform more and other tasks than before. That gave the effect of meat cutters getting an insight in what other professions work meant. The proportion of women working as meat cutters had increased. The supervisors believed there was a reduction in absenteeism, although they could not verify this in figures. They all believed the chan- ges were positive, in the longer perspective and in an ergonomics point of view. In the yearly performance appraisals meat cutters said they wanted to work as meat cutters but the rotation had meant not being as physically tired coming home from work and that was favorable.

They had not perceived any major change in their own work (Table 2). They experienced a somewhat better contact with both colleagues and employees, their responsibilities had grown and work felt more meaningfulness. Otherwise, they experienced no personal change.

Table 2

Mean values of supervisors replying to "How has your work changed qualitatively?" A 5 -grade scale, from 1 worse to 5 better and 3 no change.

$\begin{array}{lllllll}\begin{array}{l}\text { Cooperation } \\ \text { with } \\ \text { colleagues }\end{array} & \begin{array}{l}\text { Contact with } \\ \text { employees }\end{array} & \text { Responsibility } & \begin{array}{l}\text { Support and } \\ \text { help from } \\ \text { colleagues }\end{array} & \begin{array}{l}\text { Support and } \\ \text { help from a } \\ \text { superior }\end{array} & \text { Varied work } & \begin{array}{l}\text { Meaningfulne } \\ \text { ss in work }\end{array} \\ & 4 & 4 & 3 & 3 & 3 & 4 \\ \text { independent work }\end{array}$

The supervisors were clear on their role as a supervisor and as to what demands and requirements the company had on them. They described two sides. The primary task was on the well-being of the company and to be a profitable business:

- Be loyal to the company.

- To know the goals of the company and strive towards them.

- Make money: Make sure work flows and that I have a profitable department. Be cost effective.

- Show good results, produce good products, follow product specifications, maintaining quality and customer satisfaction. Deliver what we promise with the right quality.

- Follow regulations.

Next task was to see to the wellbeing of the staff, both on security but also job satisfaction and comfort issues, i.e. personnel issues:
- Take care of employees, make sure they are comfortable and feel involved and think it is fun to go to work.

- Conduct performance appraisals and make the most of the comments that comes up.

- Manage absence due to sickness and other causes through talking with employees and/or work allocation. Their objective was that no one should wear unnecessarily on his body.

- Dealing with health and safety issues through continuous improvement.

They also felt secure in a functioning network of peers and their immediate superior. All mentioned mentorship, both those having it and considered it good, and those lacking it.

On the issue of their education for their duties, all describes several of the training programs and courses they had attended. Three were dissatisfied with the lack of an individual development plan and expressed concern about the quality of the internal leadership education. The others were as a whole satisfied but talked of lifelong learning. All but one con- 
sidered themselves in need of more training in group dynamics, leadership and economics.

There was confidence to be found, where the oldest felt secure with his routine and didn't need any more training or education.

On the issue of what was lacking, one was as new as a supervisor, he didn't know what he lacked. This person had a mentor for a positive support and guidance. Four of them wished for another colleague to share the work with, alternatively less personnel or more personnel on support functions. There was not enough time for reflection or structuring the work, was an opinion expressed by all.

Most of them wanted to remain in the company and "climb in the organization", as they put it. The possibilities of developing and to make a career were perceived to be good. One supervisor was tired of this workplace and wanted to go someplace else and was looking for another job.

Two were content with what they had achieved; they talked of the good atmosphere they had created in the workplace and felt that was enough. They all clearly could see how ever changing the world of food production was and that ever new demands on them were made.

\section{Discussion}

To be a supervisor is a demanding and lonely work, and there is a need both to be a manager and a leader. A shared leadership, as four of them suggested, could mean better opportunities to do a better job and allocate resources better. In listening to the supervisors, we can detect a need for not only education and training as a manager and leader but also to have the opportunity to discuss with peers.

Most interesting was the production leaders' interest in shared leadership. The industry, in which they operate, is a traditional manufacturing industry with deep roots in Taylorism and with clear hierarchies. Finding a genuine interest in a new way to lead is encouraging and thought-provoking.

Alvesson and Sveningsson (2003) do not think that managers are most important, how the working group or team can work together is also important. Within traditional meat cutting operations that has got its limitations. Two of the most important are the noise and the production method. During the work period you are alienated by the noise and restricted by your position along the production line without a real cooperation with your work mates. Obviously, as in other line production, you are dependent on how well the detail has been handled before it gets into your hands. The next man in line in the same way depends on your skill and work. But how to perform the work, i.e. the shape of the product, is decided by the sales department as the production management decides on staffing issues. The working groups are large; the supervisor has groups of 30 persons and more.

How, then, should a supervisor act to get employees to get on well at the work place, do a good job and feel that work is meaningful? The sheer size of the working group is an obstacle. In a large group, you can easily disappear. Especially in conversations and discussions will not all be heard or speak out their opinion. In the large group there is a danger of regressive, threatening behavior from both a scared manager and the group. We all want information, to be seen and listen to and that is difficult in the large group - individuals disappear (Bergsten, 2007).

"We are the work environment of each other" is a motto that many consultants, companies and organizations would like to stand for, as can be verified by a simple Google-search. This implies the importance of managers for health and well-being of employees as employees are important for the health and wellbeing of the managers (Sandahl, Falkenström, \& Knorring, 2010).

So how should a manager be? Sandahl et al. (2010) gets at an important point when they write on how managers should act on their own feelings and experiences, not to be technocratic and cold (p.166). The difficulty lies in not to act solely on emotions, but also experience and common sense. In every situation, choose the one alternative that best serves the organization (p. 154).

Can the nature of meat cutting operations have an impact on leadership and its characteristics? It's an industry, but a very special industry. Here production not assembles, it disassembles for production. Recently, animals alive, now dead meat, are handled. The work is performed in a cold environment, by sharp tools. It can be sometimes hazardous and the possibility to communicate is scarce other than on breaks and pauses.

Does the nature of work also signify a cold leadership with poor communication? When performing the interviews I met with people who were committed to their work. I met people with a genuine interest for their business and their employees and with great determination to perform good work. They had views and constructive comments on how they could do better in the role as a supervisor. Here, they talked of two foci, production and staff, reflecting their dual 
role as promoter and developer of productivity and employees. The role they wanted to develop the most is that which deals with personnel issues. Here, production type and group size matters.

\section{Conclusions}

As a manager and leader, above all you have a responsibility to yourself. The daily questions to be answered are: Can I stand by this organization's values? Can I along with my staff achieve what the management imposes on us? This implies a need for not only education and training as a manager and leader but also to have the opportunity to discuss with peers.

To develop the supervisors' professional role requires changes in order to achieve manageable groups, and thus real opportunities to communicate. A shared leadership may be a good way to achieve creativity in the challenging task to change and improve personnel and human resources work.

\section{References}

[1] Alvesson, M., \& Sveningsson, S. (2003). Managers Doing Leadership: The Extra-Ordinarization of the Mundane. Human Relations, 56(12), 1435-1459.

[2] Badaracco, J. L., \& Hansson, S. (2003). Ledare i det tysta. Stockholm: Svenska förl. [Leading quietly] (in Swedish)

[3] Bergsten, U. (2007). Ledarskap - förståelse och handlande. [Leadership - understanding and action] Svensk idrottsforskning, 2007(2), 68-73. (in Swedish)
[4] Döös, M., Wilhelmson, L., \& Backström, T. (2010). Chefer i samarbete : om delat och utvecklande ledarskap. Malmö: Liber.

[5] Holmberg, I., \& Tyrstrup, M. (2010). Well then - What now? An everyday approach to managerial leadership. Leadership, 6(4), 353-372

[6] Håkansson, K. (1995). Diss. Förändringsstrategier i arbetslivet: [Change strategies in working life]. Göteborg. (in Swedish)

[7] Jackson, B., \& Parry, K. W. (2008). A very short, fairly interesting and reasonably cheap book about studying leadership. Los Angeles: SAGE.

[8] Karltun, J. (2010). Technical and organizational system solutions for deboning and their ergonomics implications. Paper presented at the NES2010 Proactive Ergonomics, Stavanger, Norway.

[9] Karltun, J., Aili, K., \& Vogel, K. (2011). Deboners' stress in alternatively organized work. Paper presented at the ODAM2011 Research for the missing link, Grahamstown, South Africa.

[10]Kaulio, M. A. (2008). Project leadership in multi-project settings: Findings from a critical incident study. [doi: DOI: 10.1016/j.ijproman.2007.06.005]. International Journal of Project Management, 26(4), 338-347.

[11]Klein, J. A. (1984). Why supervisors resist employee involvement. Harvard Business Review, Sept- Oct, 87-95.

[12] Sandahl, C., Falkenström, E., \& Knorring, M. v. (2010). Chef med känsla och förnuft : om professionalism och etik i ledarskapet. Stockholm: Natur \& kultur.

[13] Seger, J., \& Bergsten, U. (2007). Ledarskapscentrum vid GIH, Gymnastik- och idrottshögskolan i Stockholm. [Leadership centre at the Swedish school of sport and health sciences] Svensk idrottsforskning, 2007(2), 64-67. ( in Swedish)

[14] Vogel, K., Karltun, J., \& Eklund, J. (2010). Ergonomic changes and their consequences in a Swedish meat cutting plant. Paper presented at the NES2010 Proactive Ergonomics, Stavanger, Norway.

[15] Yukl, G., \& Lepsinger, R. (2005). Why Integrating the Leading and Managing Roles Is Essential for Organizational Effectiveness. [doi: DOI: 10.1016/j.orgdyn.2005.08.004]. Organizational Dynamics, 34(4), 361-375. 